\title{
Extreme selfing rates in the cosmopolitan brittle star species complex Amphipholis squamata: data from progeny-array and heterozygote deficiency
}

\author{
E. Boissin*, T. B. Hoareau, J. P. Féral, A. Chenuil \\ UMR 6540-DIMAR, CNRS / Université de la Méditerranée, Aix-Marseille II, Centre d'Océanologie de Marseille, \\ Station Marine d'Endoume, Chemin de la Batterie des Lions, 13007 Marseille, France
}

\begin{abstract}
Within the brittle star genus Amphipholis, individuals are generally small, gonochoric, broadcast spawners, and species often have restricted distribution areas. In contrast, A. squamata (Ophiuroidea, Echinodermata) — a species complex found worldwide - is hermaphroditic and broods its young. We used 2 complementary methods to estimate the selfing rates of this species in the northwestern Mediterranean Sea. First, we analysed 190 specimens from Les Goudes (France) using 3 codominant microsatellites and deduced the selfing rates from heterozygote deficiency, developing an original method to infer confidence intervals. Not a single heterozygote was discovered, leading to estimated selfing rates of 1.0 for all species, with an inferior limit between 0.77 and 0.98 . In 7 other European localities, not a single heterozygote was found. Second, we analysed 91 brooders and their 369 offspring using 7 nuclear markers. All progeny had DNA fingerprints identical to those of the parents, confirming that selfing rates are very high. Such high selfing rates, by contributing to colonization success (Baker's rule), may solve the paradox of cosmopolitism for these ophiuroids that lack a larval phase that would, in theory, ensure dispersal.
\end{abstract}

KEY WORDS: Self-fertilization · Species complex $\cdot$ Brooding $\cdot$ Homozygous multilocus genotype Distribution range

\section{INTRODUCTION}

Hermaphroditism is common in plants and occurs in a third of animal species (Bell 1982). When hermaphroditism is simultaneous, self-fertilization (selfing) may occur. Selfing and its evolution have been studied for a century in plants, but there are fewer studies on animals (Jarne \& Charlesworth 1993, Goodwillie et al. 2005, Jarne \& Auld 2006). The mechanism has appeared multiple times during animal evolution, and within taxa selfing may occur in isolated species. For example, the soft coral genus Alcyonium comprises both gonochoric and hermaphroditic species (McFadden et al. 2001), suggesting that selfing is not a fixed trait at the genus level. Distribution of selfing rates across species in the animal and plant kingdoms is Ushaped-with low selfing more frequently expressed than high selfing (Goodwillie et al. 2005, Jarnes \& Auld 2006) - suggesting that the median rates are probably not evolutionarily stable. Moreover, selfing rate may vary within species in both time and space (Jain 1976, Charbonnel et al. 2005), and genetic structure may be greatly affected by selfing; the main cost is inbreeding depression (Charlesworth 1992, Takebayashi \& Morrell 2001). Selfing may result in the loss of genetic diversity with a consequent reduction in adaptation to changing environments (Stebbins 1974). Self-fertilization also has a range of advantages including an assurance of reproduction in populations with low density or even without mates. Therefore, after successful dispersal of a single specimen in a new and/or free habitat, a new population may be able to develop (Baker 1955, 1967).

Whereas brittle stars are mainly gonochoric with indirect development (free planktonic larvae), Amphi- 
pholis squamata (Delle Chiaje 1828) (Ophiuroidea, Echinodermata) is a diminutive (disk diameter $<5 \mathrm{~mm}$ ) species that is simultaneously hermaphroditic, as shown by a study on maturation of male and female gonads (Alvà 1996). The species is thus regarded as capable of selfing and outcrossing. Based on RAPD dominant markers, Poulin et al. (1999) calculated a minimum outcrossing rate of 0.36. A. squamata is also viviparous (Quatrefages 1842, Fell 1946); embryos are brooded and crawl-away young are released without a free larval stage, which reduces the dispersal potential. However, in contrast to congeners that have restricted distribution areas, A. squamata is quite cosmopolitan, being found in all oceans except the polar seas (Gage et al. 1983, Hendler 1995). Sponer (2002) and Sponer \& Roy (2002) showed that A. squamata is in fact a species complex made of up very divergent mitochondrial lineages ( 7 lineages, named A to G) some of which seem endemic to geographical regions while others are cosmopolitan. The results from these two studies did not solve the paradox of a widespread distribution in this brooding species. To explain such a distribution, several conditions are necessary, viz. a dispersal event such as rafting on macroalgae or other substrata (Highsmith 1985, Edgar 1987, Bushing 1994) and then success in founding of a new population. The potential for selfing favours the founding process.

In the northwestern Mediterranean Sea, 2 main lineages of Amphipholis squamata (A and B) are present (Le Gac et al. 2004). In the area studied, on the basis of mitochondrial and nuclear data, we showed that the complex encompasses at least 4 cryptic biological species (AI, AII, AIII and B; Boissin et al. 2008). The aims of the present study were to (1) assess whether all species are capable of self-fertilization and (2) estimate the rates of selfing and outcrossing in each species. To assess the selfing rates, we used 2 complementary methods, i.e. an analysis of population deviations from Hardy-Weinberg equilibrium and a progeny-array analysis. We developed an original method to estimate confidence intervals for selfing rate that can be applied to single locus data.

\section{MATERIALS AND METHODS}

Collection. Samples were collected at Les Goudes (Marseille) in spring 2005 and spring 2006 (Table 1). On each sampling date, 1 square patch $(15 \times 15 \mathrm{~cm})$ of seaweed (coralline red algae) was scraped clear and carefully placed in a bag full of seawater. Density of ophiuroids in quadrates was very variable in time and space, with single quadrats containing from 0 to $>100$ specimens. In the area studied, highest densities were encountered during spring and summer, periods when most specimens of Amphipholis squamata were brooding and juvenile were recruited (E. Boissin, personal observation). Once back in the laboratory, we thoroughly searched for brittle stars among the seaweeds. The specimens were then either placed individually in jars until they released their progeny (spring 2005), or dissected by removing the aboral disc-cover (spring 2006) after anaesthesia by immersion in $3 \% \mathrm{w} / \mathrm{w}$ $\mathrm{MgCl}_{2}$ in sea water. If removal of the adult disc-cover revealed brooded young within the bursa, they were taken out under a binocular magnifying glass and rinsed to remove maternal tissue or fluids. They were individually preserved in $95 \%$ ethanol. To compare the mode of reproduction of populations of the species in this site with other distant populations, we also analysed samples from the northeastern Atlantic and other sites in the Mediterranean Sea (Fig. 1, Table 1).

Molecular analyses. DNA was extracted using the Chelex $10 \%$ protocol (Walsh et al. 1991). To avoid contamination of brooder-DNA with DNA of internally brooded offspring, only arm tissues were used. For juveniles, we used either the entire body or only arm

Table 1. Amphipholis squamata. Origin (locality and date) and sizes of adult and offspring samples analysed

\begin{tabular}{|c|c|c|c|c|}
\hline Region/Country & Code & Coordinates & Adults & Offspring \\
\hline Les Goudes (Provence, France) April 2005 & GOU05 & $43^{\circ} 12^{\prime} 50^{\prime \prime} \mathrm{N}, 5^{\circ} 20^{\prime} 15^{\prime \prime} \mathrm{E}$ & $190\left(45^{\mathrm{a}}\right)$ & 121 \\
\hline Les Goudes (Provence, France) May 2006 & GOU06 & $43^{\circ} 12^{\prime} 50^{\prime \prime} \mathrm{N}, 5^{\circ} 20^{\prime} 15^{\prime \prime} \mathrm{E}$ & $46^{\mathrm{a}}$ & 248 \\
\hline Total & & & $236\left(91^{\mathrm{a}}\right)$ & 369 \\
\hline White Bay (Scotland, UK) & WBA & $55^{\circ} 36^{\prime} 17^{\prime \prime} \mathrm{N}, 5^{\circ} 13^{\prime} 34^{\prime \prime} \mathrm{W}$ & 24 & - \\
\hline Helgoland (North Sea, Germany) & HEL & $54^{\circ} 11^{\prime} 34^{\prime \prime} \mathrm{N}, 7^{\circ} 53^{\prime} 21^{\prime \prime} \mathrm{E}$ & 13 & - \\
\hline Roscoff (Brittany, France) & ROS & $48^{\circ} 43^{\prime} 46^{\prime \prime} \mathrm{N}, 3^{\circ} 59^{\prime} 19^{\prime \prime} \mathrm{W}$ & 20 & - \\
\hline Arrabida (Portugal) & ARR & $38^{\circ} 32^{\prime} 53^{\prime \prime} \mathrm{N}, 9^{\circ} 12^{\prime} 23^{\prime \prime} \mathrm{W}$ & 11 & - \\
\hline Neeltje Jans (Netherlands) & NEJ & $51^{\circ} 37^{\prime} 53^{\prime \prime} \mathrm{N}, 3^{\circ} 41^{\prime} 44^{\prime \prime} \mathrm{E}$ & 12 & - \\
\hline Banyuls (southern France) & BAN & $42^{\circ} 27^{\prime} 34^{\prime \prime} \mathrm{N}, 3^{\circ} 09^{\prime} 28^{\prime \prime} \mathrm{E}$ & 29 & - \\
\hline Palazzu (Corsica, France) & PAL & $42^{\circ} 22^{\prime} 18^{\prime \prime} \mathrm{N}, 8^{\circ} 32^{\prime} 04^{\prime \prime} \mathrm{E}$ & 21 & - \\
\hline
\end{tabular}


tissues, depending on specimen size. Seven nuclear markers that produced clean, repeatable patterns were used in this study, one intron from vertebrates (intron 2 from the Actin gene, Atarhouch et al. 2003) and 6 microsatellites (Aj9 and Ai8 from Chenuil et al. 2003; AS-12, AS-14, AS-15 and AS16 from a new screening). We used thermal and $\mathrm{MgCl}_{2}$ gradients to be sure that only target loci were amplified and to obtain the most easily interpretable pattern. Table 2 gives primer sequences and annealing temperatures for the nuclear markers. Microsatellite PCR reactions were carried out under the following conditions: a denaturation step of $2 \mathrm{~min}$ at $95^{\circ} \mathrm{C}$, followed by 25 cycles of $30 \mathrm{~s}$ at $95^{\circ} \mathrm{C}, 30 \mathrm{~s}$ at the annealing temperature, $1 \mathrm{~min}$ at $72^{\circ} \mathrm{C}$ and a final elongation step of $3 \mathrm{~min}$ at $72^{\circ} \mathrm{C}$. Each reaction was carried out in a $10 \mu \mathrm{l}$ volume containing $1 \times$ buffer (Promega), $2 \mathrm{mM}$ of $\mathrm{MgCl}_{2}$, $65 \mu \mathrm{M}$ of dNTP (Invitrogen), $0.5 \mu \mathrm{M}$ of each primer

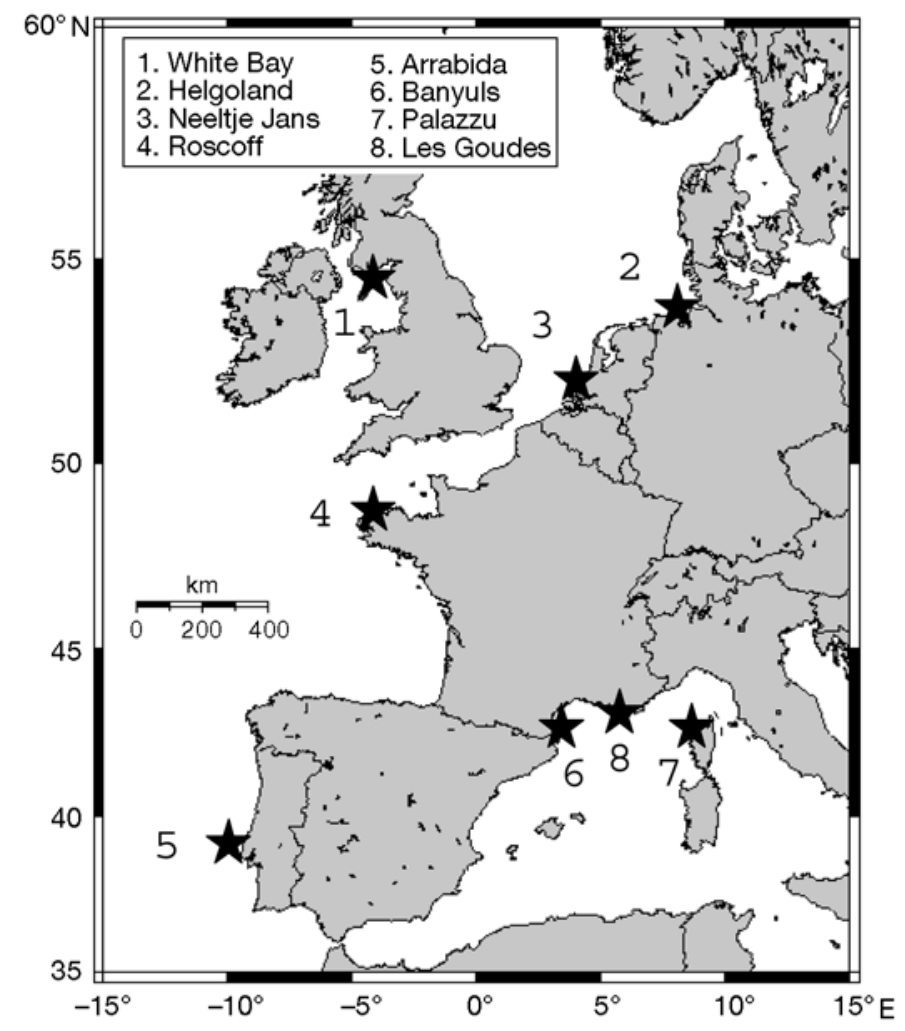

Fig. 1. Amphipholis squamata. Locations of sampling sites. Samples from 'Les Goudes' were used for progeny-array analysis. All samples were in the analysis of population genetic structure
Table 2. Amphipholis squamata. Locus names, primer sequences and optimal annealing temperature per locus $(\mathrm{T})$ for the intron (Actin2) and the 6 microsatellite markers (Ai8, Aj9, AS-12, AS-14, AS-15, AS-16) used

\begin{tabular}{|c|c|c|}
\hline Locus name & Primer sequences & $\mathrm{T}\left({ }^{\circ} \mathrm{C}\right)$ \\
\hline Actin 2 & $\begin{array}{l}\text { F: 5'-GCT ATA ACC CTC GTA GAT GGG CAC-3' } \\
\text { R: 5'-ATC TGG CAC CAC ACC TTC TAC AA-3' }\end{array}$ & 54 \\
\hline Ai8 & $\begin{array}{l}\text { F: 5'-TTA ATG CAG TAC CAC ATG AGT C-3' } \\
\text { R: 5'-GTA GGA GAG ACC TTA TGG CTG C-3' }\end{array}$ & 56 \\
\hline Aj9 & $\begin{array}{l}\text { F: 5'-AAT ATA TAT AGC TCT AAT TAC TG-3' } \\
\text { R: 5'-ATA CTA AAT TTA TAT TCA A-3' }\end{array}$ & 46 \\
\hline AS-12 & $\begin{array}{l}\text { F: 5'-AGG ATA TGG CAC CTA GAG AG-3' } \\
\text { R: 5'-TAA CTC GAA GTA CGC TCA TT-3' }\end{array}$ & 58 \\
\hline AS-14 & $\begin{array}{l}\text { F: 5'-TGC ATG CAA TAG TTA GAT GA-3' } \\
\text { R: 5'-AAT GAG TCA GAT GTC AGG AA-3' }\end{array}$ & 58 \\
\hline AS-15 & $\begin{array}{l}\text { F: 5'-CCT TCC AAG TTA CAT CGT TA-3' } \\
\text { R: 5'-ACC ATG TGG AAC AAT AGG TA-3' }\end{array}$ & 58 \\
\hline AS-16 & $\begin{array}{l}\text { F: 5'-GAT CAC AAT TGA ACT TTG AG-3' } \\
\text { R: 5'-GGT CTG CTC TTA GTG TGA GGT T-3' }\end{array}$ & 58 \\
\hline
\end{tabular}

(MWG-Biotech AG, labelled with CY5 or Fluorescein), $0.25 \mathrm{U}$ of Taq polymerase (Promega), $1 \mu \mathrm{l}$ of DNA template and sterile water up to $10 \mu \mathrm{l}$. The Actin2 intron was amplified following the procedure of Atarhouch et al. (2003). Two $\mu \mathrm{l}$ of PCR products from each individual were loaded onto an $8 \%$ denaturing polyacrylamide gel (Biorad). The PCR products were visualized with a FMBIO fluorescent imaging system (Hitachi). Allele sizes were determined using a fluorescently labelled ladder (Promega) with the FMBIO Analysis 8.0 image analyser program.

The intron and 3 microsatellite loci (AS-14, 15, 16) had multiband patterns (up to 4 bands per specimen). The loci Ai8, Aj9 and AS-12 had regular patterns of microsatellites although no heterozygote was detected. No null amplification was observed in specimens from lineage A, supporting the absence of null alleles. In order to check the most variable marker (AS$12)$, we sequenced several individuals and obtained the expected regular pattern of microsatellites (8 to 20 times TC motif repeats).

Data analyses. To estimate selfing rates, we used 2 complementary methods, 1 based on the lack of heterozygotes and the other based on progeny-array. As previously established and validated on 150 specimens (Boissin et al. 2008), because of private alleles, the combination of nuclear markers Actin2, Ai8, Aj9 allowed species assignment of each specimen.

Using the co-dominant microsatellites Aj9, Ai8 and AS-12 and the 190 specimens in the 2005 samples, we computed standard measures of genetic variability with GENETIX software (Belkhir et al. 2004), viz. nonbiased expected heterozygosity (Hnb; Nei 1978), mean number of alleles (A) and estimates of $F_{I S}$ values using the parameter of Weir \& Cockerham (1984). 
From the $\mathrm{F}_{\text {IS }}$ values, we were able to deduce the selfing rate within each species using a simple relationship applicable to an isolated unstructured population at equilibrium when mutation rate is negligible, i.e. $\mathrm{F}_{\text {IS }}=S /(2-S)$, where $S$ is the selfing rate. Available methods allowing estimation of a confidence interval for selfing rate from genotype frequency data are based on resampling schemes and require genotypes from at least 5 independent loci (Goudet 2001, available at www.unil.ch/popgen/softwares/fstat.htm). To obtain confidence intervals from single locus data, we constructed contingency tables of observed and expected numbers of specimens of each monolocus genotype for several values of selfing rate. From allelic frequencies, we calculated the expected genotype frequencies. The theoretical number of homozygotes for a given allele is given by:

$$
n_{\mathrm{i}}=\left(p_{\mathrm{i}} \times p_{\mathrm{i}}+(S / 2-S) p_{\mathrm{i}} \times q_{\mathrm{i}}\right) \times N
$$

where $p_{\mathrm{i}}$ is the frequency of the allele $\mathrm{i}, q_{\mathrm{i}}=1-p_{\mathrm{i}}$ and $N$ is the total number of specimens per species. In order to avoid cells with expected numbers of observations in the contingency table that were too low, we pooled all expected heterozygotes into the same class and all expected homozygotes into another class (they all play the same role with respect to heterozygote deficiency and selfing rate estimation). The contingency tables were therefore of size $2 \times 2$ with 4 cells,

Table 3. Amphipholis squamata. Sample size (N), microsatellite allele frequencies, number and mean number of alleles per locus (Na and A), non biased expected heterozygosity (Hnb, Nei, 1978) and heterozygote deficiency ( $\mathrm{F}_{\mathrm{IS}}$, Weir \& Cockerham 1984) within each species at Les Goudes (using 3 microsatellites) and other localities (using AS-12 only). Italics: allele sizes in base pairs. Bold numbers correspond to fixed alleles. See location codes in Table 1

\begin{tabular}{|c|c|c|c|c|c|c|c|c|c|c|c|c|c|c|c|c|}
\hline \multirow[b]{3}{*}{$\mathrm{N}$} & \multirow{2}{*}{\multicolumn{2}{|c|}{ GOU05 WBA }} & \multirow{3}{*}{$\begin{array}{c}\text { HEL } \\
13\end{array}$} & \multirow{3}{*}{\multicolumn{2}{|c|}{$\begin{array}{cc}\text { - Species A I- } \\
\text { ROS } & \text { ARR } \\
17 & 11\end{array}$}} & \multirow{3}{*}{$\begin{array}{c}\text { NEJ } \\
6\end{array}$} & \multirow{3}{*}{$\begin{array}{c}\text { BAN } \\
10\end{array}$} & \multirow{3}{*}{$\begin{array}{c}\text { PAL } \\
12\end{array}$} & \multirow{3}{*}{$\begin{array}{c}\text { Species } \\
\text { GOU05 } \\
36\end{array}$} & \multirow{3}{*}{$\begin{array}{c}\text { A II } \\
\text { PAL } \\
1\end{array}$} & \multirow{2}{*}{\multicolumn{2}{|c|}{ GOU05 WBA }} & \multicolumn{2}{|c|}{ Species A III } & \multirow{3}{*}{$\begin{array}{c}\text { BAN } \\
19\end{array}$} & \multirow{3}{*}{$\begin{array}{c}\text { PAL } \\
5\end{array}$} \\
\hline & & & & & & & & & & & & & ROS & NEJ & & \\
\hline & 93 & 14 & & & & & & & & & 33 & 1 & 3 & 6 & & \\
\hline \multicolumn{17}{|c|}{ AS-12 } \\
\hline 216 & 0.32 & 0 & 0 & 0 & 0 & 0 & 0.40 & 0 & 0.06 & 0 & 0.79 & 0 & 0 & 0 & 0.52 & 1.00 \\
\hline 218 & 0 & 0 & 1.00 & 0 & 0 & 0.67 & 0 & 0.08 & 0.42 & 0 & 0.12 & 0 & 0 & 0.17 & 0.05 & 0 \\
\hline 220 & 0.02 & 1.00 & 0 & 1.00 & 1.00 & 0.33 & 0.10 & 0.17 & 0.06 & 0 & 0.06 & 0 & 0 & 0 & 0.05 & 0 \\
\hline 222 & 0.06 & 0 & 0 & 0 & 0 & 0 & 0 & 0.08 & 0.03 & 0 & 0 & 0 & 0 & 0 & 0.38 & 0 \\
\hline 224 & 0.03 & 0 & 0 & 0 & 0 & 0 & 0 & 0.08 & 0.06 & 0 & 0 & 1.00 & 1.00 & 0.83 & 0 & 0 \\
\hline 226 & 0.01 & 0 & 0 & 0 & 0 & 0 & 0 & 0 & 0 & 0 & 0 & 0 & 0 & 0 & 0 & 0 \\
\hline 228 & 0.02 & 0 & 0 & 0 & 0 & 0 & 0 & 0 & 0 & 0 & 0 & 0 & 0 & 0 & 0 & 0 \\
\hline 230 & 0.02 & 0 & 0 & 0 & 0 & 0 & 0.10 & 0 & 0 & 1.00 & 0 & 0 & 0 & 0 & 0 & 0 \\
\hline 234 & 0.02 & 0 & 0 & 0 & 0 & 0 & 0 & 0.17 & 0.11 & 0 & 0 & 0 & 0 & 0 & 0 & 0 \\
\hline 236 & 0.01 & 0 & 0 & 0 & 0 & 0 & 0 & 0.33 & 0.28 & 0 & 0.03 & 0 & 0 & 0 & 0 & 0 \\
\hline 240 & 0.35 & 0 & 0 & 0 & 0 & 0 & 0 & 0.08 & 0 & 0 & 0 & 0 & 0 & 0 & 0 & 0 \\
\hline 246 & 0 & 0 & 0 & 0 & 0 & 0 & 0.40 & 0 & 0 & 0 & 0 & 0 & 0 & 0 & 0 & 0 \\
\hline 260 & 0.13 & 0 & 0 & 0 & 0 & 0 & 0 & 0 & 0 & 0 & 0 & 0 & 0 & 0 & 0 & 0 \\
\hline $\mathrm{Na}$ & 11 & 1 & 1 & 1 & 1 & 2 & 4 & 7 & 7 & 1 & 4 & 1 & 1 & 1 & 4 & 1 \\
\hline $\mathrm{Hnb}$ & 0.76 & 0.00 & 0.00 & 0.00 & 0.00 & 0.67 & 0.69 & 0.84 & 0.74 & 0.00 & 0.37 & 0.00 & 0.00 & 0.30 & 0.60 & 0.00 \\
\hline $\mathrm{F}_{\mathrm{IS}}$ & 1.00 & - & - & - & - & 1.00 & 1.00 & 1.00 & 1.00 & - & 1.00 & - & - & - & 1.00 & - \\
\hline \multicolumn{17}{|l|}{ Ai8 } \\
\hline 305 & 0 & - & - & - & - & - & - & - & 0.92 & - & 0 & - & - & - & - & - \\
\hline 312 & 0.97 & - & - & - & - & - & - & - & 0.08 & - & 1.00 & - & - & - & - & - \\
\hline 460 & 0.01 & - & - & - & - & - & - & - & 0 & - & 0 & - & - & - & - & - \\
\hline 700 & 0.02 & - & - & - & - & - & - & - & 0 & - & 0 & - & - & - & - & - \\
\hline $\mathrm{Na}$ & 3 & - & - & - & - & - & - & - & 2 & - & 1 & - & - & - & - & - \\
\hline Hnb & 0.06 & - & - & - & - & - & - & - & 0.15 & - & 0 & - & - & - & - & - \\
\hline $\mathrm{F}_{\mathrm{IS}}$ & 1.00 & - & - & - & - & - & - & - & 1.00 & - & 1.00 & - & - & - & - & - \\
\hline \multicolumn{17}{|l|}{ Aj9 } \\
\hline 205 & 0 & - & - & - & - & - & - & - & 0 & - & 1.00 & - & - & - & - & - \\
\hline 215 & 1.00 & - & - & - & - & - & - & - & 0 & - & 0 & - & - & - & - & - \\
\hline 223 & 0 & - & - & - & - & - & - & - & 1.00 & - & 0 & - & - & - & - & - \\
\hline $\mathrm{Na}$ & 1 & - & - & - & - & - & - & - & 1 & - & 1 & - & - & - & - & - \\
\hline Hnb & 0.00 & - & - & - & - & - & - & - & 0.00 & - & 0.00 & - & - & - & - & - \\
\hline $\mathrm{F}_{\mathrm{IS}}$ & 1.00 & - & - & - & - & - & - & - & 1.00 & - & 1.00 & - & - & - & - & - \\
\hline \multicolumn{17}{|c|}{ Multilocus } \\
\hline A & 5 & - & - & - & - & - & - & - & 3.3 & - & 2 & - & - & - & - & - \\
\hline $\mathrm{Hnb}$ & 0.27 & - & - & - & - & - & - & - & 0.29 & - & 0.12 & - & - & - & - & - \\
\hline $\mathrm{F}_{\mathrm{IS}}$ & 1.00 & - & - & - & - & - & - & - & 1.00 & - & 1.00 & - & - & - & - & - \\
\hline
\end{tabular}


i.e. expected heterozygotes, observed heterozygotes, expected homozygotes, observed homozygotes. Tests were also performed without pooling specimens and the results were similar. Discrepancies between expected and observed data were then detected using $\chi^{2}$ and exact test methods. Each method has some weaknesses: (1) in the $\chi^{2}$ method, low expected numbers of observations per cell lead to unreliability (Haberman 1988) and there were likely to be low numbers in the monolocus data for expected heterozygotes with high selfing rates, (2) the exact test requires integer values in the cells so that, in some cases, a range of selfing rates produces the same probability values (i.e. within the range $S=0.53-0.31$, the p-values are the same for species AII at locus Ai8). The lowest value of selfing rate compatible with the observed data is reached when the test becomes significant at a p-value of 0.05. To combine data from multiple loci, we summed all homozygotes and all heterozygotes and compared expected and observed values.

Finally, using all 7 nuclear markers, we searched for differences between DNA fingerprints of 91 brooders and their 369 offspring. When mutation rates are considered negligible, outcrossing can be identified unambiguously by the presence of a fragment in the offspring that is not present in the brooder.

\section{RESULTS}

\section{Genetic diversity of species}

Among the 190 specimens from spring 2005 genotyped with the microsatellite markers (Ai8, Aj9 and AS-12), 94 belonged to species AI (50\%), 36 to AII $(19 \%), 33$ to AIII $(17 \%)$ and 27 to B $(14 \%)$. While microsatellite libraries were obtained for lineage $A$, species B had null alleles at the 3 microsatellite loci

Table 4. Amphipholis squamata. Minimum selfing rate $(\min S)$ per species, monolocus and multilocus (AS-12 + Ai8) as tested with a $\chi^{2}$ method and exact tests (parentheses) at Les Goudes (see Fig. 1 for location). The upper half of the table gives values for the 2005 sample; the lower half of the table gives values after adding the 46 brooders from 2006. $\mathrm{N}=$ number of specimens analyzed

\begin{tabular}{|lcccc|}
\hline & Species AI & Species AII & Species AIII & Species B \\
\hline N (2005) & 94 & 36 & 33 & 27 \\
minS AS-12 & $0.98(0.96)$ & $0.93(0.91)$ & $0.84(0.77)$ & - \\
minS Ai8 & $0.63(0.52)$ & $0.55(0.31)$ & - & - \\
minS multilocus & $0.98(0.97)$ & $0.94(0.91)$ & $0.84(0.77)$ & - \\
N (2005 + 2006) & 110 & 51 & 42 & 31 \\
minS AS-12 & $0.98(0.97)$ & $0.96(0.93)$ & $0.92(0.86)$ & - \\
minS Ai8 & $0.88(0.81)$ & $0.85(0.74)$ & - & - \\
minS multilocus & $0.98(0.98)$ & $0.96(0.94)$ & $0.92(0.86)$ & \\
\hline
\end{tabular}

Table 5. Amphipholis squamata. Numbers of adults, adult multilocus genotypes and offspring used for the progenyarray analyses among the four species

\begin{tabular}{|lrrrr|}
\hline & AI & AII & AIII & B \\
\hline Adults & 38 & 24 & 14 & 8 \\
Adult multilocus genotypes & 30 & 22 & 11 & 4 \\
Offspring & 62 & 107 & 57 & 22 \\
\hline
\end{tabular}

and was not analysed further. Table 3 gives allelic frequencies and parameters of diversity for each species in each locality. The genetic diversity was low, 1 locus being fixed and diagnostic of 3 species (Aj9), another was variable only for AI and AII (Ai8) and the third (AS-12) had up to 11 alleles for a species. Monolocus non-biased heterozygosity values were all <0.4 excepting AI and AII for the AS-12 locus. Species AIII had the lowest mean number of alleles and the lowest non biased heterozygosity.

\section{Selfing rate estimated from $\mathrm{F}_{\mathrm{IS}}$ values}

All 190 specimens were homozygous at the 3 microsatellite loci (Ai8, Aj9 and AS-12). Consequently, the estimated $F_{\text {IS }}$ values were all 1.0 (Table 3). Confidence intervals are given in Table 4. Locus Ai8 had lower minimum selfing rates (ranging from 0.31 to 0.88 ) than locus AS-12 (ranging from 0.77 to 0.98). Multilocus estimates of minimum selfing rates were very high for the 2005 sample $(0.77$ to 0.98$)$ and higher for the pooled sample of 2005 and 2006 (0.86 to 0.98). Both tests $\left(\chi^{2}\right.$ and exact test) gave comparable minimum values of selfing, at least for multilocus data. For the remote Atlantic locations, alleles of the AS-12 locus were fixed at White Bay, Helgoland, Roscoff and Arrabida, therefore no calculations of $F_{\text {IS }}$ values were undertaken (Table 3). Moreover, at these Atlantic sites the species AIII had a common private allele different from those of Mediterranean localities. However, calculations of $F_{I S}$ values were possible for Neeltje Jans, Banyuls and Corsica samples (Table 3). We did not find heterozygote individuals in these remote samples.

\section{Selfing rate estimated from progeny- array analyses}

Brooders usually bear offspring (up to 18 per specimen) at different ontogenetic stages (from larvae to juveniles with developed arms), even within a single 
bursa. Table 5 gives the distribution of specimens among species, number of multilocus genotypes and offspring per species. In our small samples, AI had the lowest mean number of offspring per brooder (3.6) and AII had the highest (6.7). Four out of 7 nuclear markers were amplified in species B (Act2, AS-14, AS-15 and AS-16) and therefore supplied information about mode of reproduction. In all 369 broods, there was exact replication of the parent genotype. We observed neither a lack of maternal band nor extra non-maternal fragments.

\section{DISCUSSION}

\section{Mode of reproduction in the Amphipholis squamata complex}

Both the genetic structure and progeny-array analyses led to the same conclusion, viz. extremely high selffertilization rates occur in all the species of the Amphipholis squamata complex present in the area studied. Our results fit and reinforce the U-shaped distribution of selfing among plant and animal species, adding 4 points on the extreme selfing side. Differences in minimum selfing rates (confidence interval) between species are due to differences in diversity and in number of specimens, with both affecting test power rather than representing a real difference in selfing rate (as not a single heterozygote was ever observed). Moreover, both tests ( $\chi^{2}$ and exact test) gave comparable minimum values of selfing. The strongest differences (when considering locus Ai8) are probably due to the weaknesses in the 2 methods (see 'Materials and methods; Data analyses'). The assumptions made for estimating selfing rates from $\mathrm{F}_{\text {IS }}$ values (an isolated and homogeneous population and a negligible mutation rate) are probably not violated in a way that would affect our results as demographic scale dispersal potential is very limited in these species, and microsatellites had very few alleles. However, if the population is structured, minimum selfing rates may be overestimated since outcrossing between neighbours tends to produce more homozygous genotypes than in a homogeneous population. Nevertheless, the total lack of heterozygotes together with the exact replication of parent genotype point to extreme selfing rates.

Contrary to this study, a previous work on North Atlantic Amphipholis squamata populations using 3 allozymic loci (Murray 1989) suggested outcrossing, as revealed by discrepancies between maternal and offspring genotypes. Another work on 9 adults of $A$. squamata and their progeny from the Medes Islands (northwestern Mediterranean) using RAPD markers estimated a minimum outcrossing rate of 0.36 (Poulin et al. 1999). We do not know to which lineage these specimens belonged. We also suspect non-Mendelian heritability for the allozyme loci analysed by Murray (1989) since strong heterozygote excesses were observed and therefore the assessment of outcrossing may result from misinterpreted patterns. Furthermore, the dominant mode of reproduction may vary under specific local effects, leading to geographic differences. This is the case in the clam complex Lasea (Ó Foighil 1988); northeastern Pacific lineages in this complex reproduce only by parthenogenesis whereas some species in Australia reproduce only sexually. The aggregative mode of life in the species complex we studied and the occurrence of specimens in more or less isolated patches among coralline red algae in our study areas (together with densities lower than in Tindari's (Sicily) lagoons, where it can reach up to 2000 ind. $\mathrm{l}^{-1}$ of algae, Dupont \& Mallefet 1999) may favour locally high selfing rates. Bearing in mind these possible geographic differences, we analysed broadly separated Mediterranean and Atlantic samples and failed to find a single heterozygote specimen (Table 3). Nevertheless, all our samples belonged to lineage A and it would be interesting to see whether such selfing occurs in the 7 lineages of $A$. squamata described by Sponer (2002) and whether the mode of reproduction changes spatially, for example between temperate and tropical waters. Finally, our results do not rule out the possibility of episodic sexual reproduction, since after 10 generations of selfing, the proportion of heterozygotes is divided by a thousand $\left(2^{10}\right)$. The observation of frequent recombinant genotypes (Boissin et al. 2008) strongly supports this hypothesis.

Self-fertilization is the mode of sexual reproduction with the greatest possibility of producing similar parental and offspring genotypes (Stoddart 1983). However, our genetic observations could have resulted from asexual reproduction (Jarne \& Charlesworth 1993, de Meeús et al. 2007). Fell (1946) determined that Amphipholis squamata is non-fissiparous. Parthenogenesis is rare in echinoderms; the ophiuroid Ophiomyxa brevirima is one of the few brittle star species known to reproduce parthenogenetically (Garrett et al. 1997). Moreover, parthenogenesis is rare in hermaphroditic animals. This may be due to the lower advantage for a parthenogenetic mutant arising in a hermaphroditic population compared with a parthenogenetic female of the population because of the 'cost' of the male function. (Charlesworth 1980, Jarne \& Charlesworth 1996). The third argument supporting the proposition that self-fertilization is more probable than parthenogenesis comes from the anatomical structure of $A$. squamata with both male and female gonads that end in the bursae (Alvà 1996). Regardless of the details, self-fertilization and parthenogenesis 
are both selfing and would have the same overall effect on the microevolution of populations. Clearly, the main mode of reproduction for species of the northwestern Mediterranean Sea is selfing rather than cross-fertilization.

\section{Reproductive effects on genetic structure}

Microsatellite genetic diversity was relatively low $(\mathrm{A}=1$ to 13 and $\mathrm{He}=0.12$ to 0.27 , Table 3 ) in the Amphipholis squamata complex compared to nonselfing echinoderms: Strongylocentrotus droebachiensis $(\mathrm{A}=13$ to 20 and $\mathrm{He}=0.83$ to 0.91 , Addison \& Hart 2002), Tripneustes gratilla ( $\mathrm{A}=8$ to 33 and $\mathrm{He}=0.26$ to 0.96, Carlon \& Lippé 2007), Centrostephanus rodgersii ( $\mathrm{A}=4$ to 21 and $\mathrm{He}=0.32$ to 0.91, Banks et al. 2007). Low genetic diversity and multilocus homozygous genotypes are also observed in well-studied selfing species such as snails (Viard et al. 1997) and slugs (Jordaens et al. 2000). A reduction of genetic diversity by selfing is also well illustrated when comparing the outcrossing slug species Deroceras reticulatum ( 7 to 26 alleles per microsatellite) with the selfing slug species Arion intermedius (3 to 9 alleles per microsatellite, Brookes et al. 2001).

\section{Effect of selfing on colonization success}

Although self-fertilization causes a loss of genetic variability, it provides a way to reproduce when mates are in low densities (or absent), and thus it facilitates the development of populations in new habitats after colonization by only 1 ind. (founding effect). A well known rule in plants, Baker's law, highlights a correlation between the success of colonization after long distance dispersal and selfing rate (Baker 1955, 1967, Pannell \& Dorken 2006). Colonisation (and hence selfing) also appears crucial in metapopulation recovery from local extinction (Pannell \& Barrett 1998). In Amphipholis squamata, the rates of local extinction may be high (an ongoing study revealed that the pattern of density distribution seems chaotic) and may cause selection for high selfing rates. From published records, all other species of the genus Amphipholis have smaller distribution areas than A. squamata. Some species are endemic to 1 locality or restricted to 1 area: e.g. A. torelli in Greenland and Iceland (Koehler 1927, D'yakonov 1967), and A. strata and A. similis in South Africa (Clark \& Courtman-Stock 1976). Others are at most present on both sides of an ocean e.g. A. pugetana in the North Pacific (Clark 1911, D'yakonov 1967). Moreover, from the literature on the genus, $A$. squamata seems to be the only species capable of self- ing. This life history trait may account for the cosmopolitan character of a species complex with a low potential to disperse.

In summary, all species of the Amphipholis squamata complex encountered in the areas studied had extreme selfing rates. Despite the lack of a dispersal phase, some of these species have a large distribution range, being present in both the Atlantic Ocean and the Mediterranean Sea. This has been presented as a paradox in most previous studies of A. squamata. To explain the cosmopolitism of $A$. squamata, Emson et al. (1989) listed its high adaptability potential (as revealed by physiological tolerance ranges of the species; Emson \& Foote 1980), its generalist feeding requirements (Emson \& Whitfield 1989) and its capability for adapting its reproductive pattern in the face of different environmental pressure (longevity, recruitment time etc.). In addition to these ecological characteristics, selfing now appears as an important factor helping to resolve the paradox of $A$. squamata world-wide distribution. In order to understand the evolutionary forces operating on selfing rates in this ophiuroid, future studies involving different species of the complex and of the genus should attempt to determine whether selfing rates are (1) species-dependent, (2) may be influenced by density-dependent effects or (3) are a feature common to all species of the A. squamata complex.

Acknowledgements. The authors thank P. Berrebi, who permitted E.B. to use equipment at the 'Institut des Sciences de l'Evolution - UMR 5554' to conduct genetic analyses. Also, our grateful thanks to J. Goudet for advice on the estimation of confidence intervals, and S. Stöhr and P. Berrebi for the critical reading of this manuscript. The authors also thank all the sample collectors: M. Faasse from The Netherlands, M. Molis from Germany, D. Muths from Roscoff, T. Claverie from Scotland, A. Catarina from Portugal, M. Le Gac from Banyuls and J. B. Ledoux from Palazzu. This project was partly funded by 2 European networks of excellence, 'Marine Genomics Europe' and 'MarBEF' (Marine biodiversity and ecosystem functioning).

\section{LITERATURE CITED}

Addison JA, Hart MW (2002) Characterization of microsatellite loci in sea urchins (Strongylocentrotus spp.). Mol Ecol Notes 2:493-494

Alvà V (1996) Reproduction, développement, incubation et dynamique de population de l'ophiure Amphipholis squamata (Echinodermata) en Baie de Seine. PhD thesis, Université Libre de Bruxelles, Brussels

Atarhouch T, Rami M, Cattaneo-Berrebi G, Ibanez C and others (2003) Primers for EPIC amplification of intron sequences for fish and other vertebrate population genetic studies. Biotechniques 35:676-682

Baker HG (1955) Self-compatibility and establishment after 'long-distance' dispersal. Evolution 9:347-348 
Baker HG (1967) Support for Baker's law-as a rule. Evolution 21:853-856

Banks SC, Piggott MP, Williamson JE, Beheregaray LB (2007) Microsatellite DNA markers for analysis of population structure in the sea urchin Centrostephanus rodgersii. Mol Ecol Notes 7:321-323

Belkhir K, Borsa P, Chikhi L, Raufaste N, Bonhomme F (2004) GENETIX 4.05, logiciel sous Windows TM pour la génétique des populations. Laboratoire Génome, Populations, Interactions, CNRS UMR 5000, Université de Montpellier II, Montpellier

Bell G (1982) The masterpiece of nature: the evolution and genetics of sexuality. University of California Press, Berkeley, CA

Boissin E, Féral JP, Chenuil A (2008) Defining reproductively isolated units in a cryptic and syntopic species complex using mitochondrial and nuclear markers: the brooding brittle star Amphipholis squamata (Ophiuroidea). Mol Ecol 17(7):1732-1744

Brookes RC, Barker JHA, Bohan DA, Glen DM, Karp A (2001) Microsatellites for the slugs Deroceras reticulatum and Arion intermedius. Mol Ecol Notes 1:300-302

Bushing WW (1994) Biogeographic and ecological implications of kelp rafting as a dispersal vector for marine invertebrates. In: Halvorson W, Maender G (eds) Proc 4th Calif Islands Symp: update on the status of resources, March 22-25, 1994. Santa Barbara Museum of Natural History, Santa Barbara, CA, p 103-110

Carlon DB, Lippé C (2007) Eleven new microsatellite markers for the tropical sea urchin Tripneustes gratilla and crossamplification in Tripneustes ventricosa. Mol Ecol Notes 7:1002-1004

Charbonnel N, Rasatavonjizay R, Sellin E, Bremond P, Jarne P (2005) The influence of genetic factors and population dynamics on the mating system of the hermaphroditic freshwater snail Biomphalaria pfeifferi. Oikos 108: 283-296

Charlesworth B (1980) The cost of sex in relation to mating system. J Theor Biol 84:655-671

Charlesworth B (1992) Evolutionary rates in partially selffertilizing species. Am Nat 140:126-148

Chenuil A, Le Gac M, Thierry M (2003) Fast isolation of microsatellite loci of very diverse repeat motifs by library enrichment in echinoderm species, Amphipholis squamata and Echinocardium cordatum. Mol Ecol Notes 3: 324-327

Clark AM, Courtman-Stock J (1976) The echinoderms of Southern Africa. British Museum (Natural History), London

Clark HL (1911) North Pacific ophiurans in the collection of the United States National Museum. Bull US National Museum 75:1-302

De Meeús T, Prugnolle F, Agnew P (2007) Asexual reproduction: genetics and evolutionary aspects. Cell Mol Life Sci 64:1355-1372

Dupont S, Mallefet J (1999) Population dynamics of Amphipholis squamata (Echinodermata: Ophiuroidea) in the Oliveri-Tindari's lagoon system, Sicily. In: Candia Carnevali MD, Bonasoro F (eds) Proc 5th Eur Conf on Echinoderms, Milano, Italy. A.A. Balkema, Rotterdam, p 147-150

D'yakonov AM (1967) Ophiuroids of the USSR seas. Israel Program for Scientific Translations, Jerusalem [originally published in Russian: In: Strelkov AA (ed) (1954) Keys to the fauna of the USSR, Nr. 55. Zoological Institute of the Academy of Science of the USSR, Leningrad]

Edgar GJ (1987) Dispersal of faunal and floral propagules associated with drifting Macrocystis pyrifera plants. Mar Biol 95:599-610

Emson RH, Foote J (1980) Environmental tolerances and other adaptive features of intertidal rockpool echinoderms. In: Jangoux $M$ (ed) Echinoderms present and past. A.A. Balkema, Rotterdam, p 163-169

Emson RH, Whitfield PJ (1989) Aspects of the life history of a tide pool population of Amphipholis squamata (Ophiuroidea) from South Devon. J Mar Biol Assoc UK 69:27-41

Emson RH, Jones MB, Whitfield PJ (1989) Habitat and latitude differences in reproductive pattern and life-history in the cosmopolitan brittle-star Amphipholis squamata (Echinodermata). In: Ryland PS, Tyler (eds) Reproduction, genetics and distributions of marine organisms. Olsen \& Olsen, Fredensborg, p 75-81

Fell HB (1946) The embryology of the viviparous ophiuroid Amphipholis squamata (Delle Chiajei). Trans R Soc New Zealand 75:419-464

Gage JD, Pearson M, Clark AM, Paterson GLJ, Tyler PA (1983) Echinoderms of the Rockall trough and adjacent area. I. Crinoidea, Asteroidea and Ophiuroidea. Bull Brit Mus Nat Hist Zool 43:263-308

Garrett FK, Mladenov PV, Wallis GP (1997) Evidence of amictic reproduction in the brittle-star Ophiomyxa brevirima. Mar Biol 129:169-174

Goodwillie C, Kalisz S, Eckert CG (2005) The evolutionary enigma of mixed mating systems in plants: occurrence, theoretical explanations, and empirical evidence. Annu Rev Ecol Syst 36:47-79

- Haberman SJ (1988) A warning on the use of chi-squared statistics with frequency tables with small expected cell counts. J Am Stat Assoc 83:555-560

Hendler G (1995) Class Ophiuroidea. In: Hendler G, Kier PM, Miller JE, Pawson DL (eds) Sea stars, sea urchins and allies: echinoderms of Florida and the caribbean. Smithsonian Institution Press, Washington, DC, p 88-195

> Highsmith RC (1985) Floating and algal rafting as potential dispersal mechanisms in brooding invertebrates. Mar Ecol Prog Ser 25:169-179

Jain SK (1976) Evolution of inbreeding in plants. Annu Rev Ecol Evol Syst 7:469-495

Jarne P, Auld JR (2006) Animals mix it up too: the distribution of self-fertilization among hermaphroditic animals. Evolution 60:1816-1824

Jarne P, Charlesworth D (1993) The evolution of the selfing rate in functionally hermaphrodite plants and animals. Annu Rev Ecol Syst 24:441-466

> Jarne P, Charlesworth D (1996) Hermes meets Aphrodite: an animal perspective. Trends Ecol Evol 11:105-107

Jordaens K, Geenen S, Reise H, Van Riel P, Verhagen R, Backeljau $T$ (2000) Is there a geographical pattern in the breeding system of a complex of hermaphroditic slugs (Mollusca: Gastropoda: Carinarion)? Heredity 85:571-579

Koehler R (1927) Les Echinodermes des Mers d'Europe. G. Doin, Paris

Le Gac M, Féral JP, Poulin E, Veyret M, Chenuil A (2004) Identification of allopatric clades in the cosmopolitan ophiuroid species complex Amphipholis squamata (Echinodermata). The end of a paradox? Mar Ecol Prog Ser 278: 171-178

> McFadden CS, Donahue R, Hadland BK, Weston R (2001) A molecular phylogenetic analysis of reproductive trait evolution in the soft coral genus Alcyonium. Evolution 55: 54-67

Murray D (1989) Macrogeographic genetic variation in the cosmopolitan brooding brittle star, Amphipholis squamata. MSc Thesis, Mount Allison University, Sackville 
Nei M (1978) Estimation of average heterozygosity and genetic distance from a small number of individuals. Genetics 89:583-590

Ó Foighil D (1988) Random mating and planktotrophic larval development in the brooding hermaphroditic clam Lasaea-Australis (Lamarck, 1818). Veliger 31:214-221

Pannell JR, Barrett SCH (1998) Baker's law revisited: reproductive assurance in a metapopulation. Evolution 52: 657-668

Pannell JR, Dorken ME (2006) Colonisation as a common denominator in plant metapopulations and range expansions: effects on genetic diversity and sexual systems. Landscape Ecol 21:837-848

Poulin E, Florensa M, Féral JP, Cornudella L, Alva V (1999) Selfing and outcrossing in the brood protecting ophiuroid Amphipholis squamata. In: Candia Carnevali MD, Bonasoro F (eds) Proc 5th Eur Conf on Echinoderms, Milano, Italy. A.A. Balkema, Rotterdam, p 147-150

Quatrefages A (1842) La petite ophiure est vivipare. C R Acad Sci Paris 15:798-800

Sponer R (2002) Phylogeography and evolutionary history of the cosmopolitan, brooding brittle star Amphipholis squamata (Delle Chiaje, 1828; Echinodermata: Ophiuroidea).

Editorial responsibility: Otto Kinne,

Oldendorf/Luhe, Germany
PhD thesis, University of Otago, Dunedin

Sponer R, Roy M (2002) Phylogeographic analysis of the brooding brittle star Amphipholis squamata (Echinodermata) along the coast of New Zealand reveals high cryptic genetic variation and cryptic dispersal potential. Evolution 56:1954-1967

Stebbins GL (1974) Flowering plants: evolution above the species level. Harvard University Press, Cambridge, MA

Stoddart JA (1983) Asexual production of planulae in the coral Pocillopora-Damicornis. Mar Biol 76:279-284

> Takebayashi N, Morrell PL (2001) Is self-fertilization an evolutionary dead end? Revisiting an old hypothesis with genetic theories and a macroevolutionary approach. Am J Bot 88:1143-1150

Viard F, Doums C, Jarne P (1997) Selfing, sexual polymorphism and microsatellites in the hermaphroditic freshwater snail Bulinus truncatus. Proc R Soc Lond B Biol Sci 264: $39-44$

Walsh PS, Metzger DA, Higuchi R (1991) Chelex-100 as a medium for simple extraction of DNA for PCR-based typing from forensic material. Biotechniques 10:506-513

Weir BS, Cockerham CC (1984) Estimating F-statistics for the analysis of population structure. Evolution 38:1358-1370

Submitted: June 21, 2007; Accepted: January 21, 2008

Proofs received from author(s): May 30, 2008 